Archived version from NCDOCKS Institutional Repository http://libres.uncg.edu/ir/asu/

McEvoy, David. (2012). Paying to Punish on a Free Ride: Member and Nonmember Punishments in Voluntary Coalitions. Applied Economics Letters, 19(3):285-288. Published by Taylor \& Francis www.routledge.com (ISSN: 1350-4851) DOI: 10.1080/13504851.2011.572844

\title{
Paying to Punish on a free ride: member and nonmember punishments in voluntary coalitions
}

\section{David Michael McEvoy}

\begin{abstract}
We explore public good experiments in which players have the opportunity to form cooperative coalitions. The decision to join a coalition is voluntary as is a member's decision to comply with the terms of the coalition. An informal enforcement mechanism is examined in which coalition members and nonmembers can impose costly punishments on one another. We find that when punishments are purely voluntary, coalition members and freeriding nonmembers are equally likely to punish noncompliant coalition members. Moreover, the extent to which nonmembers punish noncompliance does not change regardless of whether the members can credibly enforce compliance within their coalition.
\end{abstract}

\section{Keywords}

Coalitions; Informal punishment; Public good experiments 


\section{Introduction}

Promoting participation and maintaining compliance with coalitions that are formed voluntarily is an issue of great concern, perhaps most importantly in its application to international treaties (e.g. Kyoto Protocol). The coalition structure we investigate in this study follows from a set of games developed for the analysis of cartels and international environmental agreements (e.g. Barrett, 1994; Kosfeld et al., 2009). In this study we use experiments to investigate the extent of voluntary punishment - coalition members and nonmembers having the opportunity to inflict costly punishment in response to detected cases of noncompliance and/or nonparticipation - and its effect on the level of participation and compliance with these coalitions. We compare a strictly voluntary punishment situation with one in which coalition members can credibly commit ex ante to punishing noncompliant members. We find that coalition members and free-riding nonmembers are equally likely to punish noncompliance. Moreover, the extent to which nonmembers punish noncompliance does not change regardless of whether the members can credibly enforce compliance within their coalition.

The voluntary punishment mechanism in our experiments is a type of informal sanction closely related to the institutions originally analysed by Fehr and Gachter (2000) and further investigated in a multitude of more recent studies (e.g. Fehr and Gachter, 2002; Masclet et al., 2003; Casari, 2005; Page et al., 2005; Anderson and Putterman, 2006; Bochet et al., 2006; Sefton et al., 2007; Nikiforakis and Normann, 2008). The existing body of research shows that subjects, in contrast to standard theoretical predictions, do impose costly punishments on other group members and the existence of punishment opportunities can help foster cooperation. While others have explored punishments within groups and across groups in public good games (Fehr and Fischbacher, 2004; Carpenter and Matthews, 2009), they have not explored these issues in the context of endogenous group formation. Our experiments contribute to this body of work by analysing informal punishment within and outside of coalitions that are endogenously formed to provide public goods.

\section{Experiment}

Three treatments are implemented, each with 20 subjects forming 4-person groups which are randomly reshuffled for 12 periods (i.e. strangers' design). 1 In the first stage of each treatment (coalition stage) subjects make a discrete choice whether to join a coalition in which its members agree to contribute their endowment to a public good provided that at least two players join. If less than two players join, then a coalition does not form and each player keeps their endowment. 2 If a coalition forms, the members, in stage two (compliance stage), choose whether to comply with the terms of the coalition and contribute their endowment to the public good. Nonmembers automatically choose not to contribute their endowment. The underlying game is an n-player prisoners' dilemma in which the private value of the endowment is $\$ 7$ while the public benefit of contributing the endowment is $\$ 3$ (joint pay-offs are maximized when all four players join the coalition and contribute their endowment to the public good). The baseline treatment, called no punishment, consists of only these two stages and in a Subgame- 
Perfect Nash Equilibrium (SPNE) zero contributions to the public good are made in stage two. In stage one, any level of participation is part of a Nash equilibrium.

In the voluntary punishment treatment, a third stage (punishment stage) is added in which each of the four players in a group (coalition members and nonmembers) can make mutually beneficial bilateral trades. In this stage they make a discrete choice whether to trade with each of the other three group members. If either or both trading partners choose not to trade, then both players receive $\$ 0$. Otherwise they both receive $\$ 4$. When making trading decisions, players are provided with complete information regarding the other players' decisions from the coalition and compliance stages. Thus, not trading with another group member is a form of costly punishment.4 The SPNE in this game is defined by all players trading with one another in stage three, zero contributions made to the public good in stage two and any number of players joining the coalition in stage one. In our third treatment, quasi-voluntary punishment, the only deviation compared to the voluntary punishment treatment is that coalition members commit to punishing (not trading with) noncompliant coalition members. The punishment for noncompliance is more than sufficient to motivate full compliance by risk-neutral coalition members. The SPNE in this game has all players trading with one another in stage three, full compliance by the coalition members in stage two and two players joining the coalition in stage one.

\section{Results}

The following results are based on the average provision of the public good displayed in Fig. 1, the summary statistics on punishment contained in Table 1 and regression output contained in Table 2.6 From Table 2, the number of members was statistically equivalent between the no punishment and voluntary punishment treatments $\left(\beta_{1}^{m}=0.167, p=0.174\right)$, but decreased with quasivoluntary punishment $\left(\beta_{2}^{m}=-0.217, p=0.09\right)$. From Fig. 1 and the regression results in Table 2, as predicted, the average provision of the public good did not change between the no punishment and the voluntary punishment treatments $\left(\beta_{2}^{p g}=0.117, p=0.58\right)$ but increased significantly in the quasi-voluntary punishment treatment $\left(\beta_{2}^{p g}=1.00, p<001\right)$. The trend lines in Fig. 1 exhibit typical decreasing contributions to public goods found in many public good experiments (Ledyard, 1995). 


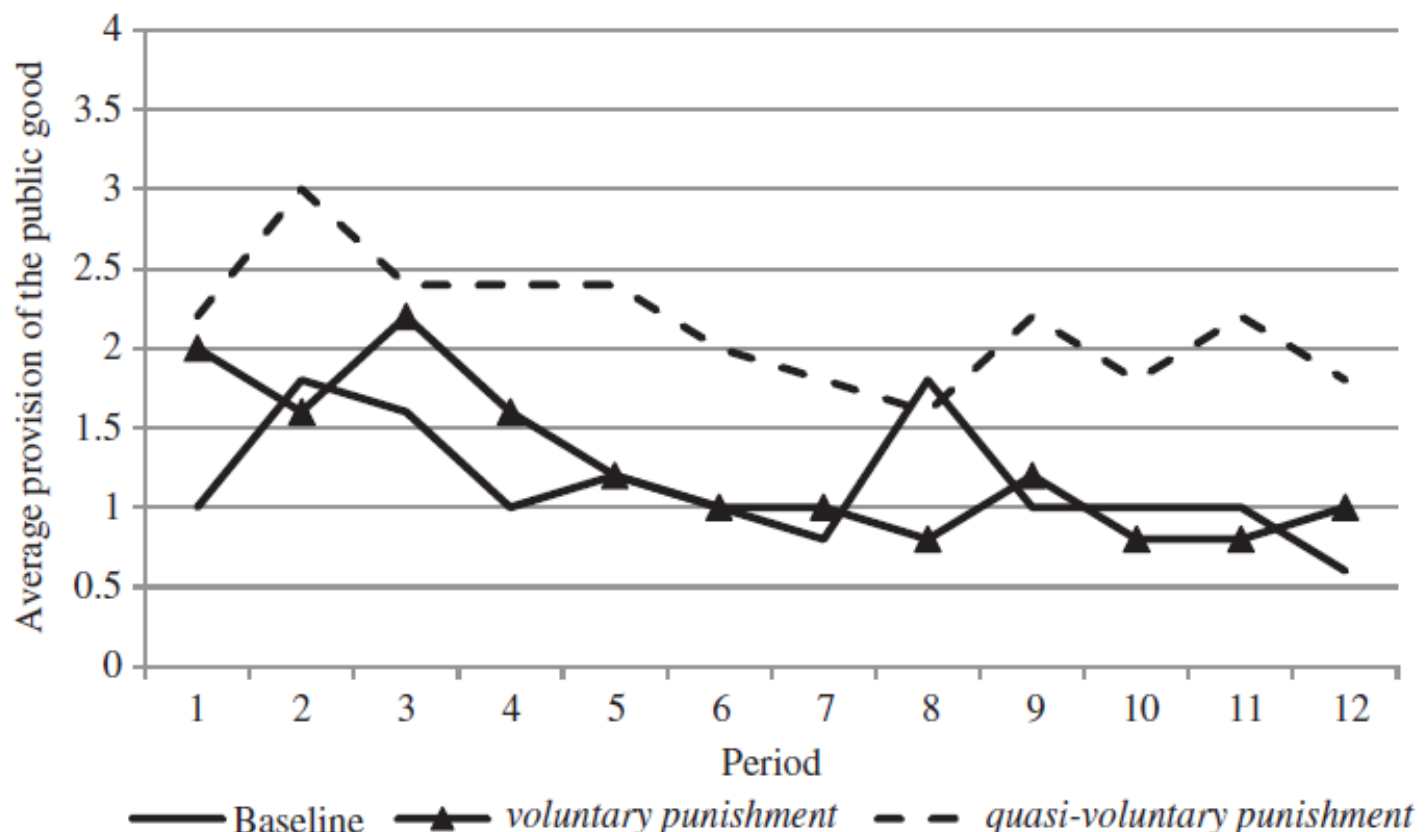

Fig. 1. Average public good provision over periods

\begin{tabular}{|c|c|c|c|c|c|c|}
\hline \multirow[b]{2}{*}{ Treatment } & \multicolumn{3}{|c|}{$\begin{array}{l}\text { Per cent of noncompliant members that were } \\
\text { sanctioned }\end{array}$} & \multicolumn{3}{|c|}{ Per cent of nonmembers that were sanctioned } \\
\hline & Total & By members & By nonmembers & Total & By members & By nonmembers \\
\hline $\begin{array}{l}\text { voluntary } \\
\text { punishment }\end{array}$ & $9.38(1.49)[384]$ & $8.81(1.59)[318]$ & $12.12(4.05)[66]$ & $14.81(3.43)[108]$ & $14.71(3.52)[102]$ & $16.67(1.67)[6]$ \\
\hline $\begin{array}{l}\text { quasi-voluntary } \\
\text { punishment }\end{array}$ & $58.33(5.41)[84]$ & $100(-)[45]$ & $10.26(4.92)[39]$ & $14.38(2.85)[153]$ & $18.49(3.58)[119]$ & $0.00(-)[34]$ \\
\hline
\end{tabular}

Note: SEs are in parentheses and the numbers of observations are in brackets.

Table 1. Summary statistics on punishing noncompliance and nonparticipation

\begin{tabular}{lllll} 
& $\begin{array}{l}\text { Public good } \\
\text { provision }\end{array}$ & $\begin{array}{l}\text { Participation when coalitions } \\
\text { formed }\end{array}$ & $\begin{array}{l}\text { Punish noncompliance } \\
\text { (binary) }\end{array}$ & $\begin{array}{l}\text { Punish nonparticipation } \\
\text { (binary) }\end{array}$ \\
\hline $\begin{array}{llll}\text { voluntary } \\
\text { punishment }\end{array}$ & $\beta_{1}^{\text {pg }}=0.117$ & $\beta_{1}^{m}=0.167$ & - & - \\
quasi-voluntary & $\beta_{2}^{p g}=1.00$ & $\beta_{2}^{m}=-0.217$ & & \\
punishment & $(0.211) p<0.001$ & $(0.122) p=0.09$ & - & $\beta_{1}^{n p}=0.264$ \\
$\begin{array}{l}\text { member to } \\
\text { member }\end{array}$ & - & - & $\beta_{1}^{n c}=0.198$ & $(0.439) p=0.548$ \\
$\begin{array}{l}\text { member to } \\
\text { nonmember }\end{array}$ & - & - & $(0.636) p=0.756$ & - \\
quasi-voluntary & - & - & - & $\beta_{2}^{n p}=2.05$ \\
punishment: & & & $\beta_{2}^{n c}=1.61$ & $(1.110) p=0.064$ \\
nonmember to & & & $(0.957) p=0.092$ & \\
$\begin{array}{l}\text { member } \\
\text { Constant }\end{array}$ & $\beta_{0}^{p g}=1.15(0.149)$ & $\beta_{0}^{m}=3.23(0.86)$ & & \\
$n$ & 180 & 172 & $\beta_{0}^{n c}=-3.64(1.34)$ & $\beta_{0}^{n p}=-3.52(1.41)$ \\
\hline
\end{tabular}

Table 2. Regression results on coalition participation, public good provision, punishing noncompliance and punishing nonparticipation 
Although punishment in response to cases of noncompliance was used sparingly (34 out of 384 cases), surprisingly, we find that a larger percentage of freeriding nonmembers punished noncompliance within coalitions compared with the percentage of coalition members that punished noncompliance. Table 1 summarizes the extent of punishment in response to noncompliance (and nonparticipation) between coalition members and nonmembers. With voluntary punishment, in $12.12 \%$ of cases in which nonmembers traded with noncompliant members, nonmembers imposed a sanction. That is, free-riding nonmembers were willing to impose costly punishments on noncompliant coalition members. On the other hand, in $8.81 \%$ of cases in which members traded with noncompliant members, the members imposed sanctions. When controlling for period and subject effects (Table 2), however, these differences are not statistically significant $\left(\beta_{1}^{n c}=0.198, p=0.756\right)$. When breaking down the $8.81 \%$ further, noncompliant coalition members rarely punished other noncompliant coalition members $(1.46 \%)$ while compliant coalition members punished noncompliance in $22.32 \%$ of cases.

Interestingly, when coalition members were committed to punishing noncompliant members (i.e. quasi-voluntary punishment) the extent to which nonmembers punished noncompliant members did not change $(a t a=0.05)$ compared to voluntary punishment $\left(\beta_{2}^{n c}=1.61, p=0.092\right)$. Therefore, despite that noncompliant coalition members were certain to be punished by all of the other coalition members in quasi-voluntary punishment, the likelihood of a nonmember punishing a coalition member in response to noncompliance did not change.

Finally, while nonmembers almost never punished nonparticipation (1 out of 40 cases, $2.5 \%$ ), over both treatments coalition members imposed punishments on nonmembers in 37 out of 221 cases (16.74\%). The likelihood of a coalition member punishing nonparticipation remained unchanged between the two treatments $\left(\beta_{1}^{n p}=0.264, p=0.548\right)$.

\section{Conclusion}

Although punishments were used sparingly, members and nonmembers were equally likely to punish noncompliance within voluntary coalitions that provide a public good, and the extent of nonmember punishment does not change regardless of whether the members can credibly enforce compliance within their coalition. We also find that the threat of purely voluntary punishment is not effective at increasing contributions to the public good, but contributions increase significantly when members can commit ex ante to punishing noncompliance. 


\section{References}

Anderson, C. and Putterman, L. (2006) Do non-strategic sanctions obey the law of demand? The demand for punishment in the voluntary contribution mechanism, Games and Economic Behavior, 54, 1-24.

Barrett, S. (1994) Self-enforcing international environmental agreements, Oxford Economic Papers, 46, 878-94.

Barrett, S. (1997) The strategy of trade sanctions in international environmental agreements, Resource and Energy Economics, 19, 345-61.

Bochet, O., Page, T. and Putterman, L. (2006) Communication and punishment in voluntary contribution experiments, Journal of Economic Behavior and Organization, 53, 11-26.

Carpenter, J. and Matthews, P. (2009) What norms trigger punishment?, Experimental Economics, 12, 272-88.

Casari, M. (2005) On the design of peer punishment experiments, Experimental Economics, 8, 107-15.

Charness, G. and Grosskopt, B. (2004) What makes cheap talk effective? Experimental evidence, Economics Letters, 83, 383-9.

Fehr, E. and Fischbacher, U. (2004) Third-party punishment and social norms, Evolution and Human Behavior, 25, 63-87.

Fehr, E. and Gachter, S. (2000) Cooperation and punishment in public goods experiments, American Economic Review, 90, 980-94.

Fehr, E. and Gachter, S. (2002) Altruistic punishment in humans, Nature, 415, 137-40. Kosfeld, M., Okada, A. and Riedl, A. (2009) Institution formation in public goods games, American Economic Review, 99, 1335-55.

Ledyard, J. (1995) Public goods: a survey of experimental research, in The Handbook of Experimental Economics (Eds.) J. H. Kagel and A. E. Roth, Princeton University Press, Princeton, NJ, pp. 111-94.

Marks, M. and Croson, R. (1998) Alternative rebate rules in the provision of a threshold public good: an experimental investigation, Journal of Public Economics, 67, 195-220.

Masclet, D., Noussair, C., Tucker, S. and Villeval, M. C. (2003) Monetary and nonmonetary punishment in the voluntary contributions mechanism, American Economic Review, 93, 366-80. 
Nikiforakis, N. and Normann, H. (2008) A comparative statics analysis of punishment in public-good experiments, Experimental Economics, 11, 358-69.

Page, T., Putterman, J. and Unel, B. (2005) Voluntary association in public goods experiments: reciprocity, mimicry and efficiency, Economic Journal, 115, 1032-53.

Sefton, M., Shupp, R. and Walker, J. (2007) The effect of rewards and sanctions in provision of public goods, Economic Inquiry, 45, 671-90. 